\title{
Salubrious Illustration and the Economics of English Herbals
}

Over the course of the sixteenth century, herbals grew from small, unillustrated octavos to giant, illustrated folios and shifted from reprints of anonymous medieval works to commissioned authorial tomes. I argue throughout this book that, by making a bibliographic turn, scholars of English herbals can better understand the context in which English botanical science developed. Thinking bibliographically about herbals requires a consideration of herbal texts from the perspective of the publishers who invested capital in their manufacture. To reveal the sophisticated and nuanced calculus of English stationers, this chapter explores the recursive relationship between readers' responses to printed herbals and the activities of the publishers who catered to them, as well as the shifting regulatory mechanisms that enabled stationers to navigate the amount of financial risk that herbal publication increasingly asked of them.

\section{The Emergence of Illustration in English Botany}

Renaissance herbals frequently contain explanations of how plants can serve as remedies for ailments, but in his I62I endorsement of study as a defense against melancholy, Robert Burton argued that even material books themselves could ease the disordered mind. Along with his recommendation that melancholics improve their moods by studying wholesome volumes of cartography, geography, and mathematics, Burton suggested that readers examine the figures of plants in large botanical books:

To see a well cut herball, all Hearbs, Trees, Flowers, Plants expressed in their proper colours to the life, as that of Mathiolus upon Dioscorides, Delacampius, Leobel, Baubinus, and that last voluminous and mighty herball of [Besler of] Noremberge, wherein almost every Plant is to his owne bignesse ... such is the excellency of those studies, that al those 
ornaments and bubbles [baubles] of wealth are not worthy to be compared to them. ${ }^{\text {I }}$

In advocating for the benefits of herbals that are "well cut" - that is, illustrated with woodcuts - Burton is by no means dismissing the medical remedies contained within these texts (he regularly cites the expertise of "herbalists" throughout his Anatomy) but is demonstrating what Heidi Brayman calls "the extent to which the very materiality of the book matters" in establishing readers' attachment to the printed medium. ${ }^{2}$ As Sachiko Kusukawa's work has detailed, herbals were among the printed genres that most benefited from new technological developments in book illustration, so it is unsurprising that Burton finds that herbals' salubrious effects can be gained not just by reading but by gazing upon their engraved or woodcut pictures of plants. ${ }^{3}$ To that end, the large-format herbals that Burton explains are of particularly healthful use are those widely known for their distinctive illustrations, like the Czech edition of Pietro Andrea Mattioli's 1544 commentary on Dioscorides with new, full-page woodcut illustrations (Prague, 1562; USTC 568706); Pierre Pena and Matthias de L'Obel's Stirpium aduersaria noua (London, I570-I; STC 19595); Jacques Dalechamps's Historia generalis plantarum (Lyon, 1586-1587; USTC 83985); and the Prodromos theatri botanici of Swiss physician Caspar Bauhin (Frankfurt am Main, I620; USTC 213579I), an illustrated preamble to what would later be his magnum opus, Pinax theatri botanici (Basel, 1623; USTC 2045504). Since Burton was writing his Anatomy with the resources of Oxford's Bodleian Library close to hand, his awareness of large, illustrated continental herbals is unsurprising, and it explains his ability to access a copy of Basilius Besler's notoriously expensive florilegium Hortus Eystettensis (Eichstädt, I6I3), which featured copperplate engravings of plants intended to show, in extravagant detail, the riches of that particular garden. ${ }^{4}$

Burton's investment in the affordances of printed botanical illustrations is of a piece with the health effects of "reading green" that Leah Knight

I Robert Burton, The Anatomy of Melancholy (Oxford: John Lichfield and James Short for Henry Cripps, I62I), sig. Zir.

${ }^{2}$ Heidi Brayman Hackel, Reading Material in Early Modern England: Print, Gender, and Literacy (Cambridge: Cambridge University Press, 2005), I.

3 Kusukawa, Picturing the Book of Nature.

4 William Ostler notes that "so laden with quotations is the Anatomy that it has been called "The Sweepings of the Bodleian"” ("The Library of Robert Burton," Proceedings and Papers of the Oxford Bibliographical Society [Oxford: Oxford University Press, I922-I926], I82-I90; I84). On the printing and publication of Hortus Eystettensis, see Nicholas Barker, Hortus Eystettensis: The Bishop's Garden and Bessler's Magnificent Book (London: British Library, 1994). 
finds is a recurrent feature of seventeenth-century English literary culture, including the phenomenon's association with the elite readers who could afford such large and lavishly illustrated books. ${ }^{5}$ As Knight shows, the recursive effects of "green reading" could be seen not only in approaches to wellness but also in architecture and interior design, as Renaissance readers manipulated the leaves of herbal texts into new forms as imagined and literal decor. Leonhart Fuchs, who was particularly invested in illustration, puts the benefits of such books this way:

there is the wondrous pleasure that will permeate your soul on contemplating so many kinds of plants and will invite you not only to the love, but to the defense, of herbal medicine. For what could be more pleasurable, more enjoyable, than to gaze upon plants, which Almighty God has painted with so many varied colors, has decked with the most elegant flowers, whose colors no painter ever could completely express, and then has adorned with fruits and seeds of the greatest use as condiments and medicine? ${ }^{6}$

As I discussed in Chapter I, Fuchs's account of the beauty of his herbal conveniently elides the mechanical reproductive processes of printing and publishing that make such "wondrous pleasures" available to readers. More ironically, Fuchs's celebration of gazing upon books also inadvertently endorses the position of his rival, printer Christian Egenolff, as Egenolff copied the illustrative woodcuts of Fuchs's and Brunfels's herbals on the grounds that the natural world could be copywritten only by God himself. For Fuchs, the material forms of printed herbals are not a surrogate but a supplement to real-world botanical experience, useful primarily because their pictures can spur others to the godly and wholesome study of plants. The book is an inspiration, in other words, one that can force people out of their studies and into the fields to marvel in God's creation.

Given that Renaissance readers had such widespread appreciation for botanical illustrations, it is not surprising, then, that printed images of plants also found their way into the needlecraft of gentlewomen by providing them with patterns. The herbalist John Parkinson recognized this potential in his Paradisi in sole paradisus terrestris (London, I629):

Although Borage and Buglosse might as fitly haue been placed, I confesse, in the Kitchen Garden, in regard they are wholly in a manner spent for Physicall properties, or for the Pot, yet because anciently they haue been entertained into Gardens of pleasure, their flowers hauing been in some respect, in that they haue alwaies been interposed among the flowers of

5 Leah Knight, Reading Green in Early Modern England (Burlington, VT: Ashgate, 2014).

${ }^{6}$ Meyer et al., Great Herbal, I:218. 
womens needle-worke, I am more willing to giue them place here then thrust them into obscurity. ${ }^{7}$

Parkinson's woodcut illustrations in Paradisi are roughly four times larger than those in other herbals, taking up the entirety of the folio's page, and it is small wonder that women would find them useful as patterns for needlecraft (Figure 3.I). As Rebecca Laroche suggests, Elizabeth Isham made use of the woodcuts of printed botanical books like Parkinson's in just this way to quiet her agitated mind. ${ }^{8}$ Isham's autobiographical diary, dated I638/9, reveals that through embroidery she "delight[ed] much in [flowers'] seuerall shaps \& collers ... it kept me from those thoughts $\mathrm{w}$ [hich] was hurtfull to me," seemingly echoing the way that her contemporary Robert Burton also made use of printed herbals to distract from his own melancholy. ${ }^{9}$ Other readers found these books so attractive that they were dangerously distracting: the diary of Puritan Samuel Ward lists looking at herbals among sinful behaviors: "May 17, 1595. Thy wandring mynd on herbals att prayer tyme, and at common place. Also thy gluttony the night before."

By the time that Robert Burton and Elizabeth Isham were writing in the I630s, herbals had been so long associated with botanical illustrations that they had become a requisite part of the genre. Samuel Ward's remarks suggest that botanical illustrations in printed books may have been appealing - and potentially damnable - even forty decades earlier. Yet, though the benefits of pictures now seem obvious to readers, particularly those inclined to marvel at herbals for their beauty, Renaissance authors' appreciation of printed book illustration emerged more slowly. Not all authors of works of natural history or medicine were initially convinced that illustrations were useful substitutes for traditional verbal description.

7 John Parkinson, Paradisi in sole paradisus terrestris (London, 1629), sig. X5r. On the relationship between herbals and women's embroidery, see Jennifer Monroe, Gender and the Garden in Early Modern English Literature (Burlington, VT: Ashgate, 2008) and Linda Levy Peck, Costuming Splendor: Society and Culture in Seventeenth-Century England (Cambridge: Cambridge University Press, 2005).

${ }^{8}$ Laroche reports that a copy of Parkinson's Theatrum botanicum, now housed at the Library of Congress, features "eighteenth-century embroidery patterns ... pressed between the pages" (Medical Authority, I28).

9 On the relationship between needlecraft and textuality, see Jones and Stallybrass, Renaissance Clothing, esp. chap. 6. On the manner in which Isham's textual process is figured through her embroidery, see Laroche, Medical Authority, esp. chap. 3, and Margaret J. M. Ezell, "Elizabeth Isham's Books of Remembrance and Forgetting," Modern Philology Io9 (20II): 7I-84. See also Susan Frye, Pens and Needles: Women's Textualities in Early Modern England (Philadelphia: University of Pennsylvania Press, 2010).

Io M. M. Knappen, ed., Two Elizabethan Puritan Diaries (Chicago: American Society of Church History, 1933), I03-104. 


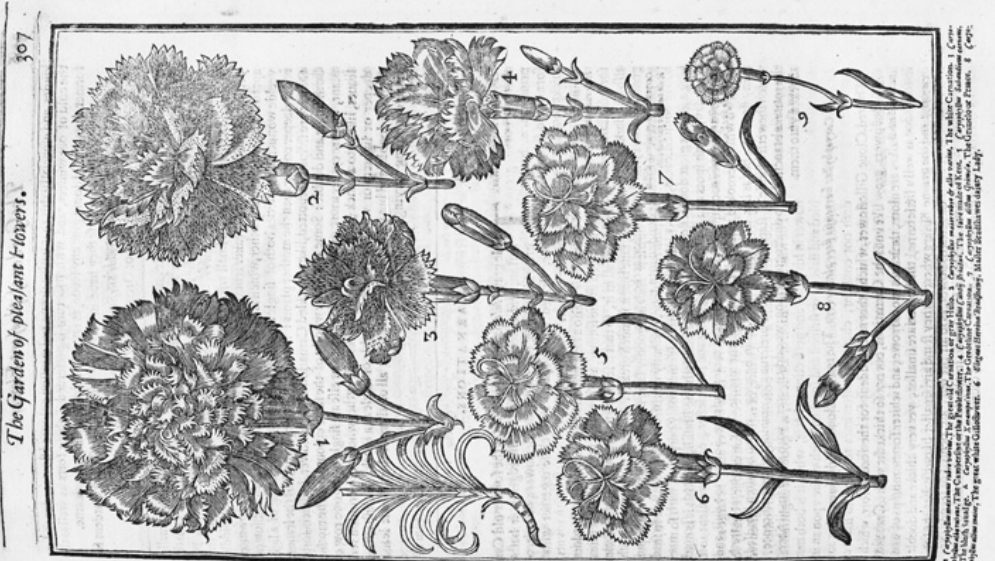

ปี

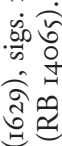

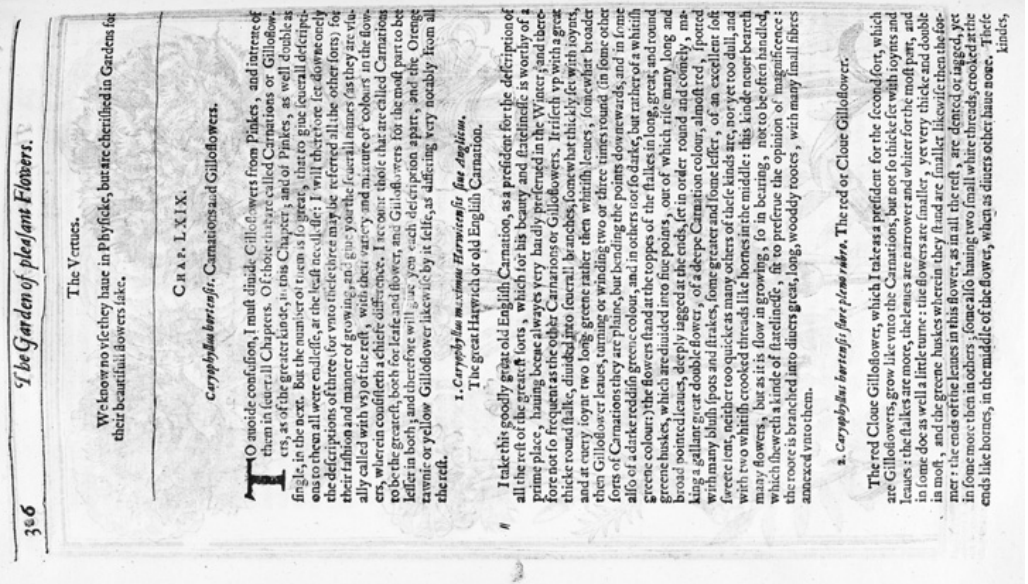


Like Thomas Johnson in his account of bananas discussed in the Prologue, some authors were concerned that portraits drawn from living examples represented only a particular specimen and thus were inadequate to describe a species' fuller, more varied appearance. ${ }^{\text {II }}$ Copious and detailed verbal descriptions that required readers to apply their own judgment as they evaluated their particular specimens could be seen as far more useful. Nonetheless, a combination of the advancement in printers' technical expertise and an increased authorial investment in illustration eventually enabled herbals to be used as identification tools for the description and classification of plant species that early modern English readers found at home and abroad. ${ }^{\mathrm{I} 2}$ These improvements in both the form and the content of herbals were valued both by needleworkers and by melancholics.

While the typically large folio size of these publications limited their utility as field guides, the comprehensive nature of their verbal texts in outlining plants' agricultural and medicinal virtues made them of pragmatic interest to medical practitioners, scholars, and literate laypeople alike. In some cases, a demand for large books could lead directly to the production of smaller ones. After experiencing the indignity of seeing his carefully designed woodcut images for De historia stirpium copied for a translation of Dioscorides's De materia medica by the Frankfurt publisher Christian Egenolff, Leonard Fuchs had smaller copies of the images recut for Primi de historia stirpium (Basel, 1545), an octavo edition of a muchreduced text of De historia stirpium designed to be used in the field. Likewise, William Ram created an unillustrated abridgment of Henry Lyte's English translation of Rembert Dodoens's Cruydeboeck (Antwerp, 1554) that he titled Ram's Little Dodeon [sic] (London, I606; STC 6988). Ram wrote that he hoped to make the most salient features of Dodoens and Lyte's work available to readers unable to afford the large volume by "draw[ing] that into a handful, which before was in the compass of a great garden: or else to bring that into a little Garde[n] which before was (as to be looked for in many fields and disperced places) not to be found but by great labour and industry). ${ }^{\text {'3 }}$ Ram suggested that he needed

II On natural historians' ambivalence to illustrations, see Kusukwa, Picturing the Book of Nature and Ogilvie, Science of Describing.

${ }^{\text {I2 }}$ For further examination of the role played by illustration in the publishing history of herbals, see Sachiko Kusukawa, "Illustrating Nature," in Marina Frasca Spada and Nick Jardine, eds., Books and the Sciences in History (Cambridge: Cambridge University Press, 2000), 90-II3; on Renaissance usage of naturalism, see James S. Ackerman, "Scientific Illustration," in Allan Ellenius, ed., The Natural Sciences and the Arts (Uppsala: Almqvist \& Wiksell International, 1985), I-I7.

${ }^{2}$ William Ram, Ram's Little Dodeon (London: Simon Stafford, I606), sig. A2v. 
to create the epitome to serve the underprivileged, but deserving, herbal reader:

So as where the geat $[s i c]$ booke at large is not to be had, but at a great price, which ca[n]not be procured by the pooer sort, my endeuor herein hath bin chiefly, to make the benefit of so good, necessary, and profitable a worke, to be brought within the reach and compasse aswell of you my poore Countrymen \& women, whose liues, healths, ease and welfare is to be regarded with the rest, at a smaller price, than the greater Volume is. ${ }^{\text {I4 }}$

The publisher Simon Stafford, however, took his time bringing the book into print: though he entered the volume into the Stationers' Registers on June 9, I600, Stafford didn't actually print Ram's epitome until I606, and he never reprinted it. ${ }^{\text {I5 }}$ For Stafford, then, the little book didn't seem especially "profitable" after all.

What herbal authors' hesitancy about illustration means is that, for a time, the images accompanying printed works were not drawn from authors' descriptions but supplied from publishers' existing stocks of woodcuts, many of which were copied from manuscripts. Wynkyn de Worde's I495 English translation of Bartholomaeus Anglicus's illustrated encyclopedia De proprietatibus rerum (The Properties of Things, STC 1536) features a chapter on botany headed by a large woodcut of an orchard foregrounded by a field of plants. Even by the standards of incunabula, de Worde's early woodcuts are primitive, likely copied from his manuscript original, and the single illustration accompanying the chapter on trees offers little to make De proprietatibus rerum useful to fifteenth-century readers as a tool to identify distinct specimens of plants and herbs. ${ }^{{ }^{6}}$ Though the leaves on the trees in de Worde's woodcut differ slightly from each other, they largely share the same trunk morphology, while the herbs in the foreground are similarly patterned rather than distinctive. Over the next century, however, two publishers saw enough in Bartholomaeus Anglicus's text to risk publishing it again. Thomas Berthelet's edition appeared in an unillustrated version in 1535 (STC I537), and Thomas East published an updated and revised version in 1582 (STC 1538) after he entered the work into the Stationers' Company Registers.

\footnotetext{
${ }^{14}$ Ram, Rams Little Dodeon, sig. A2r. Lyte's revised edition in I586 (STC 6986) required I25.5 editionsheets per copy; Ram's epitome was a quarter of the size (32 sheets).

Is Arber, Transcript, 3:162.

${ }^{16}$ Edward Hodnett, English Woodcuts I480-I535 (London: Bibliographical Society, I973), Io.
} 


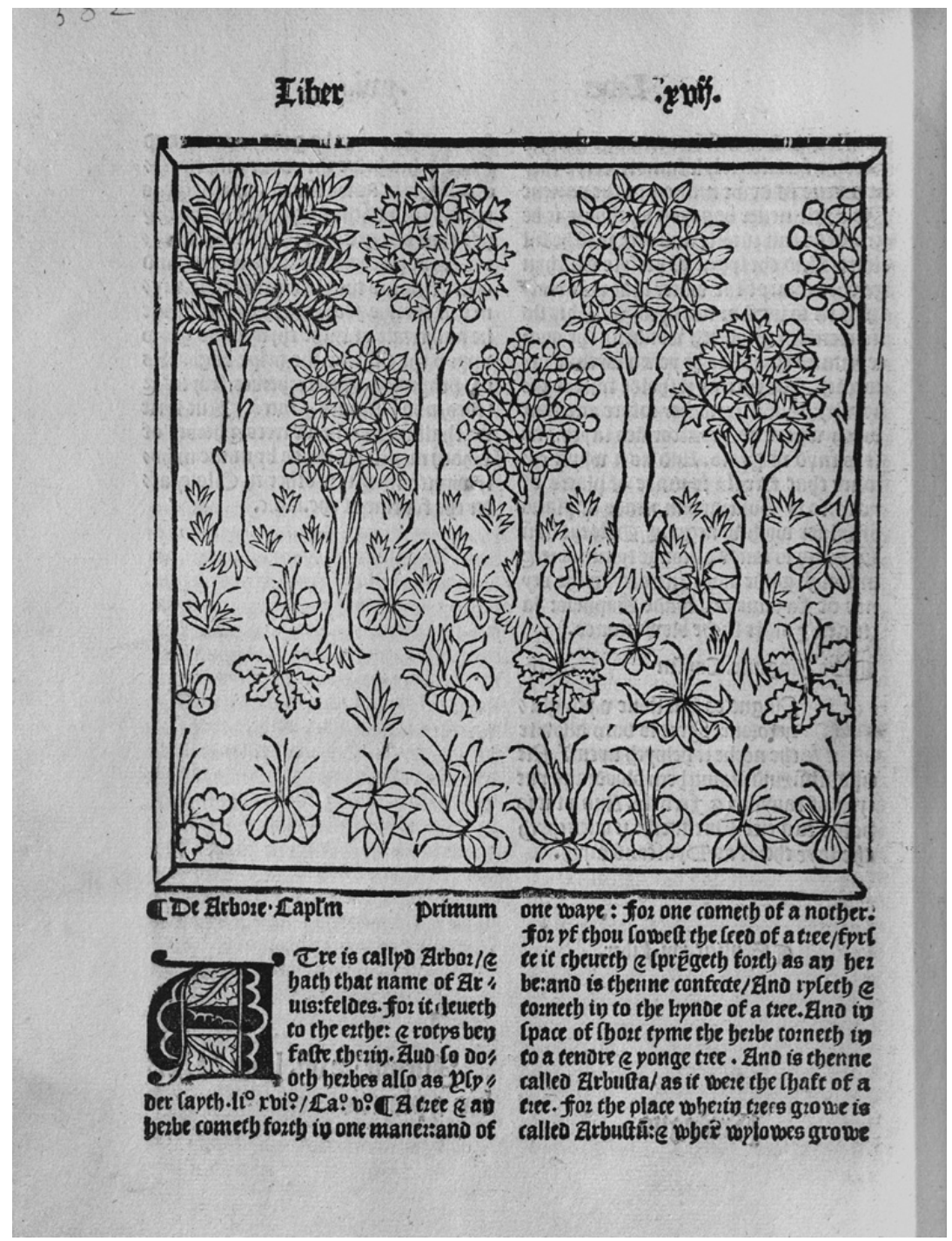

Figure 3.2 De proprietatibus rerum (I495), sig. M5v. By courtesy of the Department of Special Collections, Memorial Library, University of Wisconsin-Madison

(Thordarson 230).

Between Berthelet's edition of 1535 and East's publication of De proprietatibus in 1582 occurred a turning point for botanical book illustration. Brunfels's and Fuchs's illustrated herbals were extremely popular on the 
continent, going through dozens of editions in multiple vernacular languages. Despite being printed abroad, their books often appear in English library catalogues and booklists, suggesting that they were regularly imported. ${ }^{17}$ In England, William Turner's three-volume A New Herball (I55I-I568) and Pierre Pena and Matthias de L'Obel's Stirpium aduersaria noua (I570-I57I) were likewise authoritative volumes that offered clarifying illustrations to accompany individual plant descriptions wherever possible. East's De proprietatibus bears evidence of the publisher's awareness of this shift in readers' expectations for botanical book illustration, as does the new woodcut that East commissioned for his edited text; the image clearly exhibits the artist's awareness both of distinct species of plants, like the plantain (bottom left) and violet (bottom right), and of the changing trunk shapes that might result from the different locales where trees might grow. The tree overlooking the river slopes down towards the water, while its roots mound to keep it fixed firmly on the bank. East's decision to change the botanical illustration accompanying his text (he could simply have commissioned copies of the I495 woodcut instead of designing a new one) demonstrates the ways that Elizabethan publishers considered the norms established by other printed books in the marketplace as they added features and affordances to distinguish new volumes. ${ }^{\mathrm{I}}{ }^{8}$ As Chapters 4 and 5 will show, this attentiveness to generic norms was observed even fifty years earlier, as Henrician, Edwardian, and Marian publishers likewise considered the competing books offered for sale by their contemporaries as they brought their own books to market, innovating wherever they perceived an opportunity to distinguish their product.

The first illustrated book printed in England exclusively devoted to the study of plants appeared in 1526, the year after Bankes's edition of the little Herball offered the first appearance of the word "herbal" in print. However, the illustrations in Peter Treveris's The Grete Herball (STC I3I76) suffered from some of the same problems as those in de Worde's edition of De proprietatibus. Treveris's Grete Herball contains 48I

${ }^{17}$ Leedham-Green, Books in Cambridge Inventories.

I8 The fact that each of East's woodcut images was printed on one side of a single folio leaf for insertion, as an individual leaf, into the appropriate gathering is curious. In this regard, his woodcuts resemble illustrations made from engraved and/or etched copperplates. Because the latter had to be printed on a specialized rolling press, they often appear on inserted leaves of the kind we see in East's book. Woodcuts, however, can be positioned alongside movable type and, because of this, were usually printed as part of regular gatherings. The fact that East's woodcuts were printed in an atypical manner, separately from the sheets of printed text, might suggest that their inclusion was an afterthought or that the illustrations were designed to allow sale separately from the rest of the volume. 


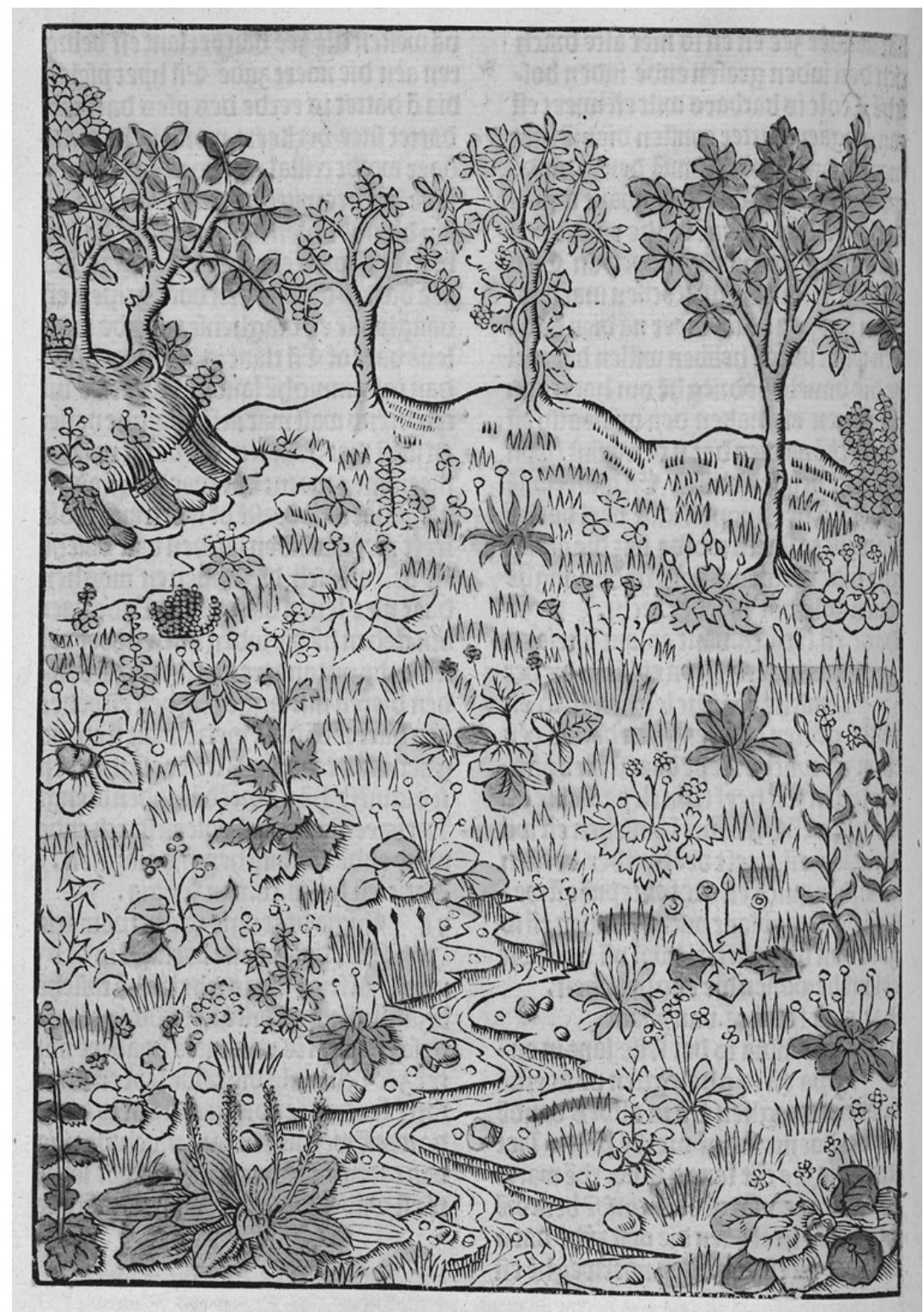

Figure 3.3 De proprietatibus rerum (I582), a page inserted between sigs. Zz5v and Zz6r. The Huntington Library, San Marino, California (RB 970I7). 
woodcut illustrations of plants and animals, which, as Edward Hodnett notes, was "the record for an English press" at the time. ${ }^{19}$ As with de Worde's text, however, precision in the rendering of illustrations suffered at the level of accuracy; Blanche Henrey calls The Grete Herball s pictures "completely out of touch with nature." 20 Though attractive, many of the figures are deliberately stylized to fit into the woodblocks, and the occasionally preternatural and Galenic doctrine of the late medieval text is aptly represented in the accompanying illustrations, where mandrakes look like men and plants both flower and produce fruit at the same time. ${ }^{2 \mathrm{II}}$ In addition, some of the same figures are repeated as representing different species of plants, complicating attempts an early modern reader might make to use The Grete Herball as a guide to identification. I will explore the publication history of Treveris's Grete Herbal more fully in Chapter 5. My interest here is to use illustrated herbals to demonstrate more broadly some of the ways that early modern English stationers evaluated the existing market of books when they considered the viability of their own speculative publications.

While the "slavish copying" of medieval botanical manuscripts followed herbals in their initial foray into print, ${ }^{22}$ some authors and compilers of Renaissance herbals began to include their own experiential accounts of plants, and such interest soon led to herbals' inclusion of botanical images drawn from life. The German Herbarius (Mainz, I484; USTC 740862), an illustrated work printed by Johannes Gutenberg's sometime foreman Peter Schoeffer, appears to be the first example of a printed herbal text in any language that was primarily written from firsthand knowledge. ${ }^{23}$ The preface to the German Herbarius claims that it was the joint work of a wealthy traveler to the east and a Frankfurt physician. ${ }^{24}$ The Herbarum vivae icones (Strasburg, I530-1536; USTC 662094) of Otto Brunfels promised its readers "living portraits of plants," while, as I've noted, Leonard Fuchs's De historia stirpium commentarii insignes (Basel, 1542) sought precision in every detail, including in the rendering of the text's printed images. Along with a woodcut portrait of the author, the opening pages of De historia stirpium featured portraits of De historia's various craftsmen at

19 Hodnett, English Woodcuts, 63. ${ }^{20}$ Henrey, British Botanical, I:2I.

${ }^{21}$ On contemporary debate over the usefulness of botanical illustration in the identification of plants for medical purposes, see Kusukawa, "Illustrating Nature."

22 The term is quoted from John Gilmor, British Botanists (London: William Collins, I944), 8.

${ }^{23}$ Henrey, British Botanical, I:5-6; Arber, Herbals, i8.

${ }^{24}$ For a translation of the preface to the second edition of the German Herbarius, see Arber, Herbals, $23-26$. 


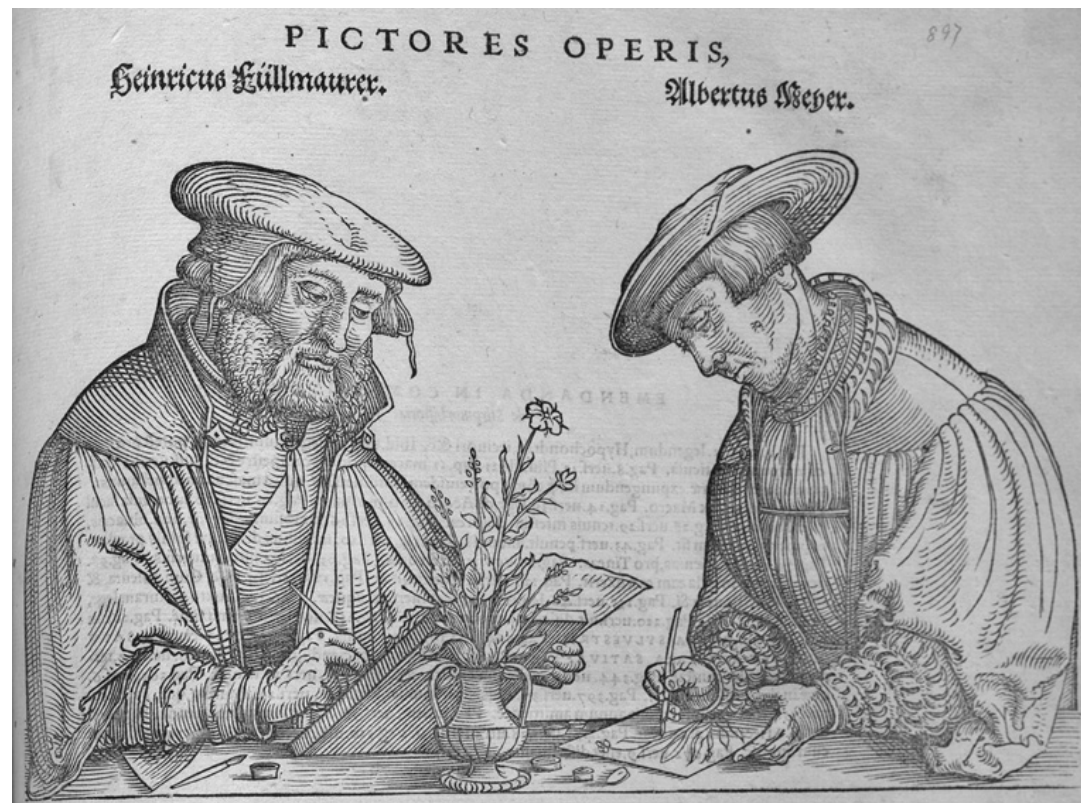

S C V L P T O R Ditu6 3rosolph. Spectle.

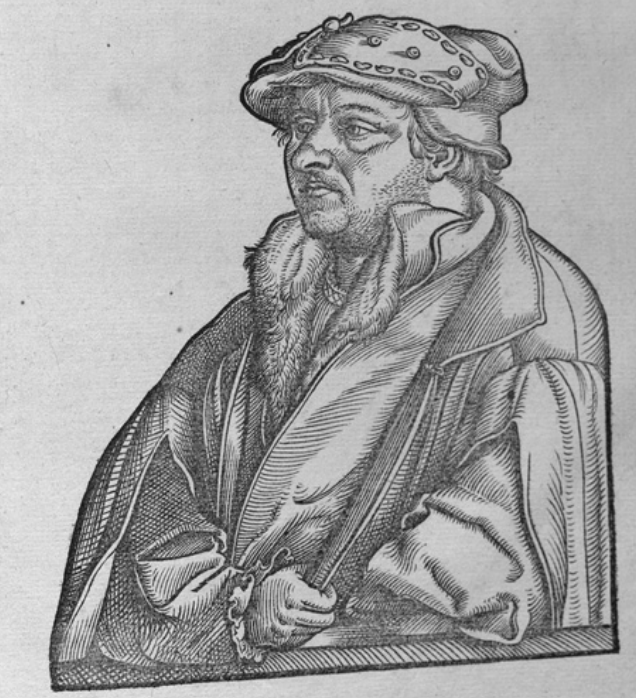

Figure 3.4 Portraits of the illustrators and block-cutter of De historia stirpium (I542). By courtesy of the Department of Special Collections, Memorial Library, University of Wisconsin-Madison (Thordarson T I65I). 
work illustrating directly from the plants themselves and transferring the images to the woodblocks before the woodblocks were cut by Viet Rudolf Speckle (Figure 3.4). ${ }^{25}$

Fuchs was expressly invested in the utility of illustrations to reinforce the extent of his own botanical investigations, and he instructed his artists to use a diachronic strategy to display the various stages of a plant through the seasons to illuminate bud, flower, and fruit. Fuchs's illustrations display the entire plant right down to the root and both sides of a leaf, and varietals among a particular species might also be displayed as if they were growing on a single plant to show diversity while also minimizing the number of separate woodcuts needed in the volume. His accompanying text suggests that Fuchs assumed considerable botanical foreknowledge among his readership, and Kusukawa demonstrates that Fuchs uses his book's illustrations to provoke his readers' recall of sensible features of known plants (like taste and smell) to enable them to "adjudicate[] between competing opinions among ancient and contemporary authorities. ${ }^{26}$ In this way, the technology of printed images constituted Fuchs's contribution to a raging humanist debate between the proper relations of theory and practice, particularly in the practice of medicine. Rather than the practice of reading standing in as a surrogate for firsthand expertise, the publication of an illustrated printed book could serve as an authoritative supplement designed to arbitrate readers' own experience of handling plants. As Kusukawa persuasively argues, "[t]exts worked in tandem with pictures to produce a powerful form of argument - a visual argument, encompassing both demonstration and persuasion," and authors like Fuchs exploited the new affordances available to them in the medium of the printed book to promote their professional agendas. ${ }^{27}$

\section{Thinking Materially}

Though it is easy to represent these developments in botanical illustration as a simple linear progression (herbal images were crude and then they became more sophisticated), the history of English herbals in print reveals that the process was recursive. After all, authors create texts, not books, and the concerns of those who make and market the codicological vehicles in which verbal texts find their readers do not always align with the

\footnotetext{
25 See Sachiko Kusukawa, "Leonard Fuchs on the Importance of Pictures," Journal of the History of Ideas 58 (1997): 403-427.

26 Kusukawa, Picturing the Book of Nature, 122.

27 Kusukawa, Picturing the Book of Nature, 250-25I.
} 
preoccupations of authors. The progression in Renaissance naturalism was not linear either, as later publishers and compilers often copied classificatory images that had initially been drawn from an author's personal experience and placed them in "un-authorized" new contexts. The woodcuts of plants and herbs that illustrated the German Herbarius were for decades copied by other continental publishers in their own botanical books. Similarly, despite their author's efforts to defend a visual and verbal ethos in plant description and the efforts of the publisher to name the artists within the volume, the woodcuts in De historia stirpium were quickly divorced from Fuchs's text to join the works of other authors, much to his dismay. Fuchs's woodcuts were so popular that they were copied by herbals in Germany and the Low Countries, and reproductions of the images eventually found their way into William Turner's A New Herball, which was so celebrated for being the first of the great English herbals that Turner is widely heralded as the "Father of British Botany." (That the illustrations to Turner's magnum opus were copied from Fuchs often goes unmentioned in such celebratory accounts.)

As the genre of illustrated herbals became more familiar to English readers over the course of the sixteenth century, these botanical works gradually grew in both size and scope, cumulating in such extensive books as Turner's three-volume $A$ New Herbal (I55I-I568) but also in the I,400plus-page folio of John Gerard's Herball or General Historie of Plantes of I597 and in the equally massive Theatrum botanicum of John Parkinson published in 1640. The names of these large, illustrated folio herbals frequently turn up in the libraries of physicians and apothecaries, a reasonable inclusion given the attention that herbals typically pay to the use of plants in treating ailments and disease. Mention of these folio herbals also crops up in the diaries and account books of aristocratic women who worked as lay healers: Grace Mildmay specifically mentions Turner's A New Herball in her diary; Margaret Hoby has "the Herball" read to her three times in 1599; while Anne Clifford is featured in her great triptych portrait at Appleby Castle standing in front of a wall of books that includes a manuscript epitome of Gerard's. ${ }^{28}$ Given his declared interest in

${ }^{28}$ On Mildmay, see Linda Pollock, With Faith and Physic: The Life of a Tudor Gentlewoman Lady Grace Mildmay, I552-I620 (New York: St. Martin’s Press, 1993). On Hoby, see Margaret Hoby, The Private Life of an Elizabethan Lady: The Diary of Lady Margaret Hoby, I599-1605, ed. Joanna Moody (Stroud: Sutton Publishing, 1998) and Laroche, Medical Authority. On Clifford, see Mary Ellen Lamb, "The Agency of the Split Subject: Lady Anne Clifford and the Uses of Reading," English Literary Renaissance 22 (1992): 347-368; 365. Critics have misidentified the work as a printed copy of Gerard's Herball, but Rebecca Laroche points out that, as an epitome, the volume in the 
illustrated herbals, it is perhaps not surprising that Robert Burton singled out his copy of Gerard's Herball in his will to bequeath it to one "Mrs Iles." ${ }^{29}$ Such an itemized note testifies that Burton saw Gerard's Herball as an especially valued book to pass along, and Blanche Henrey provides evidence that Gerard remained in use as a standard botanical textbook through to the nineteenth century. ${ }^{30}$ Indeed, scholars still regularly invoke Gerard's, Turner's, and Parkinson's illustrated herbals as authorities: editors of early modern texts view them as valuable resources that explain early modern authors' medical and botanical knowledge. ${ }^{3 \mathrm{I}}$

And well they should - the large English folio herbals, whose authors are widely heralded as the fathers of British botany, are thick, informative compendia. Their contents contain "the names and descriptions of herbs, or of plants in general, with their properties and virtues," and they bear evidence of their authors' study of other printed and manuscript herbals as well as their own informed experience as gardeners. The images in these books served as a vital means for disseminating visual information about exotic "New World" varietals that few old world botanists ever got to see firsthand. Gerard's herbal of 1597 offered readers the first printed illustration of the potato, while, as we've seen, Thomas Johnson's 1633 revision of Gerard offered what was then cutting-edge: a cross-sectioned banana. ${ }^{32}$ Over the course of the sixteenth and seventeenth centuries, herbals grew through such botanical one-upmanship until their ever-more comprehensive contents reached the upper limits of binding a single-volume codex. Such accumulated bulk accounts for Richard Cotes's choice of words when he entered Parkinson's Theatrum botanicum in the Stationers' Registers as "an herball of a Large extent." 33

painting better displays Clifford's deliberate effort at self-fashioning in echoing her mother's alchemical practice (see Medical Authority, I7-18).

29 Osler, "Library," I84. ${ }^{30}$ Henrey, British Botanical, I:53

${ }^{31}$ A few representative examples taken from the Arden Shakespeare series: James C. Bulman cites Gerard to explain "mandrake," the nickname whores gave Justice Shallow in King Henry IV, Part II (London: Bloomsbury, 2016), 315; A. S. Cairncross cites Parkinson's Paradisus terrestris in his note on "balm" in his edition of The Third Part of King Henry VI (London: Bloomsbury, 1964), Ir6; R. A. Foakes cites both Turner and Gerard in a note on "century" in his edition of King Lear (London: Bloomsbury, 1997), 322.

32 As Redcliffe N. Salaman notes in The History and Social Influence of the Potato (Cambridge: Cambridge University Press, 1949), the potato's absence from Nicholas Monardes's Joyful News out of the New World (first English translation, 1577) and William Turner's works of I55I-I568 offers a "a datum line before which we may be reasonably certain that the potato was unknown in Europe" (77). The first printed mention of the potato was in Gerard's Latin catalogue of the plants in his Holborn garden in 1596 (Papus orbiculatus), Englished in its translated edition of 1599 to "Bastard potatoes."

${ }_{33}$ Emphasis mine. See Arber, Transcript, 4:307. 
Yet, as the impressive popularity of the unillustrated Herball first published by Richard Bankes in I525 suggests, such heavily illustrated folio herbals did not emerge from print shops sui generis, invested in by their publishers simply on the grounds that a market for such vernacular works likely existed in England as readily as it did on the continent. Publishing a work such as Gerard's Herball in 1597 required a substantial outlay of capital to purchase or rent not only the book's 2,200 woodcuts but also sufficient paper for the entire print run, the printer's expenses for composition and presswork, and the copy of the manuscript produced by Gerard. To better compare the costs involved in publishing books of various sizes, bibliographers invoke a unit of measurement known as an "edition-sheet." Because a four-page (two-leaf) folio, an eight-page (four-leaf) quarto, and a sixteen-page (eight-leaf) octavo gathering are all created from one sheet of paper, considering the total number of sheets of paper required to print a copy of a book allows for a comparison of relative cost among formats. ${ }^{34}$ Each copy of Gerard's 1597 folio Herball, for example, contained 37I edition-sheets, so a print run of 500 copies of the volume would have required the Nortons to purchase I85,500 sheets of large-size paper, more than 386 reams. ${ }^{35}$ (Printing a single copy of Bankes's 1525 quarto Herball, by contrast, needed only nine edition-sheets.) The cost and quality of white paper suitable for printing varied, but the paper used in a volume of comparable format, the 1596 edition of John Foxe's Book of Martyrs, cost seven shillings a ream; at such a rate, the paper alone for the 1597 Herball would have cost its publishers more than $\mathrm{E}_{3} 35$ before a single word or image had been printed upon it. ${ }^{36}$ Once the paper and Gerard's manuscript copy had been acquired, the booksellers Bonham and John Norton needed to provide the printer, Edmund Bollifant, with these supplies, as well as with sufficient funds to employ Bollifant's workers in manufacturing the massive volume. In order for a herbal to be printed, publishers' significant material and financial concerns needed to be accommodated. Illustrations required woodblocks to be manufactured, rented, or purchased, and large illustrated texts could be financed only by the wealthiest stationers.

34 Blayney, Printers of London, 938-939.

35 I am calculating a ream of twenty quires at twenty-four sheets per quire. Blayney, Printers of London, IOO-IOI; see also "Publication of Playbooks," 408-4IO.

${ }^{36}$ This amount assumes a print run of 500 copies. The figure for the paper cost of Book of Martyrs comes from W. W. Greg and Eleanore Boswell, eds., Records of the Court of the Stationers' Company 1576-I602 from Register B (London: The Bibliographical Society, I930), 5I. 


\section{Managing Risk}

Early modern publishers could not begin selling copies of books and recouping their costs until every page of every copy of a volume had been printed, and they still would not break even until they had sold about two-thirds of the books wholesale to other booksellers. ${ }^{37}$ Such risks to financial outlay in the creation of an edition motivated stationers to pay the fee to license their right to copy and record their intention to print a particular work within their civic organization, the Stationers' Company. While some earlier Tudor publishers held individual time-limited, crownissued patents that protected their editions from piracy (I will detail these patents more in Chapter 4), the Stationers' incorporation in 1557 granted the Company the legal means to assert control over the technology of print. Only members of the Company were now permitted to do so, and all stationers were required to license their titles in advance. The earliest records post-incorporation record payments of the Company's licensing fee. $^{38}$

As the edition-sheet totals for herbals like Gerard's suggests, printed book manufacturing was expensive and financially risky. What protected stationers' investments was the Company's internal regulations: once the right to copy a title had been claimed, another stationer could not also print an edition of the text without risking Company sanction. Licensing was therefore largely designed to protect members' economic investments: "it was problems of infringement, rather than of censorship, that the Company's license was intended to regulate." 39 An extant record of a stationer having paid for a license to publish a work was typically recorded in an entry in the Stationers' Registers, and thus has since come to be known as a "register entry." Such licenses could be exchanged, bequeathed, or transferred among stationers. ${ }^{40}$ Register entries were primarily designed to record the fee that the Company charged for a license to print a work, but they eventually also came to indicate, within the Stationers' Company, a stationer's ownership of a particular textual property and their right to profit from the income that property could generate through print publication. Under the rights granted to the Stationers by virtue of their charter, precautions such as licensing enabled the Company to charge anyone who usurped a stationer's right to copy with a breach of

\footnotetext{
37 For an overview of the economics of book publication in the period, see Blayney, "Publication of Playbooks."

38 Peter W. M. Blayney, "If It Looks like a Register ...," The Library (20I9): 230-242; 239.

39 Blayney, "Publication of Playbooks," 399. 40 Blayney, "Publication of Playbooks," 400.
} 
contract, subjecting the thief to fine and seizure of the surreptitious copies. ${ }^{4 \mathrm{I}}$ Without the insurance of Register entries, even wealthy stationers such as the Nortons could not afford to hazard their finances on such largescale products as bibles, lawbooks, and herbals, as avaricious colleagues could, in theory, have easily appropriated others' finished texts and reprinted them to sell at a reduced price.

There were additional costs to putting a book into press for the first time. The editorial labor involved in compiling, organizing, and (especially in the case of large books like Gerard's Herball) indexing a text only affected the profits of its first edition; a page-for-page reprint of a text required little new editorial work. Yet, while sizable folios with complicated editorial constraints such as bibles and statutes of law were always in popular and professional demand, the market for more specialized treatments of scientific and literary subjects usually needed to be readily established by smaller projects along similar themes before a publisher would reasonably invest in a larger book. Only after a clear market for Francis Beaumont and John Fletcher's play quartos was demonstrated, for example, did it make sense for the publishers Humphrey Moseley and Humphrey Robinson to risk their capital publishing a folio of their collected dramatic works. ${ }^{42}$ Similarly, before examining the Nortons' or other publishers' investments in the illustrated herbal phenomena of the latter half of the sixteenth century and first decades of the seventeenth, it will be helpful to investigate the period when the market for such works was first established.

This discussion brings us back, at last, to the first and most popular printed herbal in early modern England: the unillustrated little Herball of I 525 that was first printed by Richard Bankes. With eighteen editions in less

4I Some publishers also sought ad hoc patents, which gave them a monopoly on a title, genre, or given class of books, enabling them to seek redress of illicit copyists with the backing authority of the crown. (Books and sheets printed with the protection of such patents did not need to be entered into the Registers.) Such patents for genres like playbills were derived from the "generic" or all-purpose privileges that a number of individual printers and booksellers had held prior to I557, which entitled them to remove their new titles from the public domain for a fixed period of time.

${ }^{42}$ In his introduction to the readers of the Beaumont and Fletcher folio of I647 (Wing Bi58I), Moseley explains that the widespread availability of printed quartos of many of Beaumont and Fletcher's plays necessitated his avoidance of including them in his collection, to avoid his being accused of codicological double-dipping: "I would have none Say, they pay twice for the Same book" (sig. A4r). Along with his dismissal of the seemingly ubiquitous quartos, contrasting the nascent Beaumont and Fletcher folio with other books is an important part of Moseley's marketing strategy; the convenience of the current printing of the authors "entirely New" plays together in a single tome is offered in a direct contrast to other collections that are "commonly but a new Impression, the Scattered pieces which were printed Single, being then onely Republished together: 'Tis otherwise here" (sig. A4r). 
than fifty years, this small book was a runaway bestseller, and the Herballs demonstrated profitability for many publishers later made it possible for the larger, illustrated herbals of William Turner and John Gerard to be produced. The little Herball does more than simply pave the way for later, larger editions, though: as different publishers experimented with different ways of presenting the Herball in print, they tested new affordances and marketing strategies that would influence how English readers would respond to the herbal genre. The decisions made by innovative publishers like Robert Wyer and William Copland as they repackaged the little Herball demonstrate that authority - and authors - gradually became a useful mechanism for distinguishing one's wares in the competitive print marketplace of early modern London. 